\title{
Visceral obesity in normal-weight patients suffering from chronic schizophrenia
}

\author{
Beata Konarzewska ${ }^{1 *}$, Ewa Stefańska², Agnieszka Wendołowicz² ${ }^{2}$ Urszula Cwalina ${ }^{3}$, Anna Golonko², \\ Aleksandra Małus ${ }^{1}$, Urszula Kowzan ${ }^{1}$, Agata Szulc ${ }^{1,4}$, Leszek Rudzki ${ }^{1}$ and Lucyna Ostrowska ${ }^{2}$
}

\begin{abstract}
Background: BMI (body mass index) can be misleading regarding the level of adiposity in a normal-weight individual. Recently, a bioelectrical impedance analysis (BIA) method was developed that can measure body composition variables. The main objectives of this study were to use BIA to compare the body composition variables between chronic nondiabetic schizophrenic patients with normal weight and healthy individuals. The secondary objective was to compare the nutritional pattern of schizophrenia patients with that of matched healthy subjects, and to identify possible relationships between the content of different components of their diet and visceral adiposity.

Methods: The subjects were 52 normal-weight patients (33 males and 19 females) diagnosed with schizophrenia based on the DSM-IV and 45 (23 males and 22 females) BMI- matched controls. The patients had been receiving atypical or typical antipsychotic agents for at least one year before enrollment into the study but continuously for 3 months preceding the study and were psychiatrically stable. Body fat (kg), percent (\%) body fat, fat-free mass, VAT (visceral adipose tissue) and SAT (subcutaneous adipose tissue) were measured using the bioelectrical impedance analysis (BIA) method. Daily food rations (DFR) were quantitatively evaluated by a 24-h dietary recall method covering 3 days preceding the examination.
\end{abstract}

Results: In normal-weight patients schizophrenia was significantly linked with higher VAT, VAT/SAT ratio and lower fat- free mass. Men had over 5 times and women over 2 times as much VAT as BMI matched groups. In women with schizophrenia and in their controls, the amount of magnesium, niacin and vitamin B6 in their diet inversely correlated with VAT, while in men lower zinc and vitamin C intake was related to higher visceral adiposity.

Conclusions: Our study has shown that normal-weight patients with chronic schizophrenia have higher levels of visceral fat (VAT) than controls but similar volume of subcutaneous adipose tissue (SAT). Although no clear conclusion can be made regarding cause-and-effect relationships between the dietary content of food served to our patients and visceral obesity, we suggest that schizophrenia diet should be further investigated as a possible factor related to this type of obesity.

Keywords: Schizophrenia, Normal weight, Body composition, Bioelectrical impedance

\section{Background}

In 1981, Ruderman described the phenotype of "metabolically obese but normal weight" (MONW) individuals [1]. These lean individuals mark a departure from common human patterns, in which a metabolic disease is a consequence of weight gain. MONW subjects display an altered insulin sensitivity and a higher abdominal and

\footnotetext{
* Correspondence: beatajan0@op.pl

'Department of Psychiatry, Medical University of Bialystok, Plac Brodowicza 1, Choroszcz 16-070, Poland

Full list of author information is available at the end of the article
}

visceral adiposity. Visceral obesity puts a strain on the entire circulatory system leading to raised blood cholesterol and triglyceride levels, lower HDL cholesterol levels, increased likelihood of overall cardiovascular risk and associated morbidity and mortality [2,3]. As subjects with visceral obesity might have normal weight, they may escape detection and may not benefit from adequate early prevention of metabolic syndrome [4]. Most schizophrenic patients under neuroleptic treatment gain weight $[5,6]$. However, some of them maintain a normal weight, despite long-term pharmacotherapy and eating 
habits similar to those of overweight patients [4]. It is known that patients with schizophrenia make poor dietary choices and they have a tendency to $[7,8]$ have increased caloric intake, including a higher total dietary fat consumption than healthy individuals [8]. Usually, they are also physically inactive; they spend most of the time passively [9-11]. They have higher levels of cortisol and insulin prior to neuroleptic treatment, which make them particularly susceptible to the accumulation of visceral fat [12]. Previous studies which have found an increased visceral adiposity in schizophrenic patients analyzed patients with both normal and abnormal body weight, and not always a test and control group were adjusted for BMI $[13,14]$. None of them focused entirely on normal-weight patients. These individuals may as well present an unfavorable metabolic body composition and significant visceral obesity even though they had normal body weight.

BMI is a commonly used measure in people with schizophrenia, but there are no data indicating its sensitivity and specificity as an indicator of visceral adiposity among this clinical group. Both BMI and waist circumference are more strongly correlated with subcutaneous (SAT) than with visceral fat (VAT). Although BMI correlates highly with fat mass, depending on level of muscularity, it can be misleading regarding the level of adiposity of an normal weight individual [15]. Recently, a bioelectrical impedance analysis (BIA) method was developed that can measure body composition variables [16]. BIA is based on the principle that there is less resistance to an alternating current passing through tissues that contain fluids and electrolytes than through those containing relatively high amounts of lipids [17]. Its results correlate well with the results of dual energy X-ray absorptiometry (DXA) [18].

The main objectives of this study were to use BIA to compare the body composition variables between chronic non-diabetic schizophrenic patients with normal weight $\left(\mathrm{BMI}<25 \mathrm{~kg} / \mathrm{m}^{2}\right)$ and healthy individuals. We sought to define the magnitude of visceral obesity in both groups in terms of elevated VAT volumes. The second objective was to compare the schizophrenia patients, who in previous studies appeared to have a poor diet $[7,8]$ with matched healthy subjects and to identify possible relationships between the content of different components of their diet and visceral adiposity. We hypothesized that schizophrenia patients food intake which contains inadequate amounts of fibre, vitamins and minerals might be linked with the tendency to accumulate visceral fat.

\section{Methods}

\section{Participants}

This study was conducted between October 2012 and March 2013. The subjects were 52 normal-weight (BMI < $25 \mathrm{~kg} / \mathrm{m}^{2}$ ) patients (33 males and 19 females) treated in
Psychiatric Hospital, Social Care Unit for Mentally Disabled Patients in Choroszcz and Day Care Center in Bialystok (Poland). They were diagnosed with schizophrenia disorder based on the DSM-IV diagnostic criteria. The age of schizophrenia onset and the length of the disease for males and females were as follows (males 28.9 years; 12.2 years) and (females 25.4 years; 13.2 years). As a reference group, 45 matched healthy subjects (23 males and 22 females) were also included. Patients had been receiving atypical or typical antipsychotic agents for at least one year before enrollment into the study but continuously for 3 months preceding the study and were psychiatrically stable. Medication doses in men and women at the time of the study expressed as chlorpromazine equivalents were as follows (males $891.1 \mathrm{mg}$; females $722.1 \mathrm{mg}$ ).

Sixteen of them have been receiving 1 neuroleptic, 17 patients- 2 or 3 neuroleptics, concomitantly. The most commonly used were: olanzapine, risperidone, haloperidol and clozapine. Exclusion criteria included serious and unstable medical conditions, cognitive disorders, substance dependence within the previous 3 months, known medical conditions which might affect changes in metabolic parameters, known history of diabetes (patients with glucose levels $\geq 126 \mathrm{mg} / \mathrm{dL}$ were excluded from the study) or lipid disorder, use of anti-diabetic or lipid-lowering therapy and special diets to lower glucose or lipids levels. The study was approved by the Bioethical Committee of the Medical University of Bialystok, Poland. Informed written consent was obtained from all the subjects after explanation of the nature, purpose, and potential risks of the study.

\section{Procedures}

After providing written informed consent, each subject underwent a physical examination and a psychiatric diagnostic evaluation. Anthropometric measures, including weight, height, umbilicus waist circumference and hip circumference, were obtained. Body composition was measured by means of a bioelectrical impedance analysis (BIA) technique using a Maltron body fat analyzer (Maltron BioScan 920) with an operating frequency of $50 \mathrm{kHz}$ at $800 \mu \mathrm{A}$ [19]. All measurements were taken around the same time of the day after patients have sat quietly and rested for at least $15 \mathrm{~min}$. The participants lay supine on a non-conducting surface with their arms abducted from the trunk and legs slightly separated for 5 minutes. Four electrodes and cables were attached to the right hand and ankle, as shown in the user's manual. When the measurements stabilized, the analyzer displayed bioelectrical impedance directly and immediately through the calculation of the software. According to the strong relationships among measured impedance, fat-free mass (FFM), and total body water, many prediction equations were developed to estimate 
percentage of body fat and FFM [20]. These 2 types of data, the percentage of body fat and FFM, could also be directly displayed after BIA measurement. Previous studies demonstrated excellent test-retest reliability for BIAobtained measurements, with correlation coefficients ranging from .96 to .99 for resistance measurements [21]. Hydrostatic weighing and BIA-predicted correlation coefficients range from .71 to .93 , with standard errors of estimate ranging from $2.7 \%$ to $4.7 \%$ body fat [22]. The measurement procedure required that the subject should stand barefoot on the analyzer and hold a pair of handgrips, one in each hand. The device uses a multiplefrequency $(5 \mathrm{kHz}, 50 \mathrm{kHz}, 250 \mathrm{kHz}$, and $500 \mathrm{kHz}$ ) BIA technology and has 8 tactile electrodes: 2 are in contact with the palm and thumb of each hand, and 2 are in contact with the anterior and posterior aspect of the sole of each foot. To calculate the body fat, percent (\%) body fat, fat- free mass, VAT (visceral adipose tissue), SAT (subcutaneous adipose tissue), muscle mass, and body water for the entire body, the MC-190 uses a proprietary equation developed by the manufacturer.

Daily food rations (DFR) were quantitatively evaluated by a 24-h dietary recall method covering 3 days preceding the examination. The portion sizes of dishes and food products were estimated based on the "Photo Album of Food Products and Dishes" [23]. The energy and nutritional values of the diets were calculated with Diet 5 computer software designed by the Institute of Food and Feeding (IFF) in Warsaw. The findings were compared with the recommended dietary allowance (RDA) or Adequate Intake (AI) proposed by the IFF for healthy adults who report low physical activity [24]. The mean demand for energy and basic nutrients was determined individually referring to due body mass. The intake of protein at $0.9 \mathrm{~g} / \mathrm{kg}$ of due body mass and fat covering $30 \%$ of the anticipated energy demand was referred to as the norm. The carbohydrate demand was calculated from the difference between daily energy demand and the energy derived from protein and fats. The demand for saturated and mono- and polyunsaturated fatty acids was determined at $10 \%, 12 \%$ and $8 \%$ of energy demand, respectively. The daily norm for dietary fibre was $30 \mathrm{~g}$, whereas for dietary cholesterol it was not more than $300 \mathrm{mg}$.

\section{Statystical analysis}

Due to the small size of the groups we used nonparametric tests. To compare the main demographic and clinical characteristics between patients and controls, Mann-Whitney $U$ test was performed. Descriptive statistics were calculated as median with the interquartile range: median (IQR). Multiple linear regression analysis was employed to analyze the continuous variables of body composition (independent variables were: gender, the occurrence of schizophrenia, age and BMI). Healthy women were used as the reference category The relationship between selected variables were evaluated using the Spearman correlation coefficient. A value of $\mathrm{p}<0.05$ was considered significant. The data were analyzed using the package Statistica 10.0 StatSoft.

\section{Results}

The basic characteristics and body composition of participants are presented in Tables 1 and 2.

There were no statistical between-group differences in age, body mass, height and BMI. In females, WHR (waist hip ratio) was significantly higher in patients with schizophrenia than in healthy individuals. RMR (resting metabolic rate) and fat free mass $(\mathrm{kg})$, were in all groups positively correlated (males with schizophrenia $\mathrm{r}=073$, $\mathrm{p}=<0.001, \mathrm{n}=33$, controls $\mathrm{r}=0.83, \mathrm{p}=\mathrm{p}=<0.001, \mathrm{n}=23$; women schizophrenia $0.53, \mathrm{p}=0.02, \mathrm{n}=19$, controls $\mathrm{r}=$ $0.56, \mathrm{p}=0.007, \mathrm{n}=22$ ). Furthermore, RMR and fat free mass were significantly lower in patients with schizophrenia than in healthy individuals (Table 1). Both groups of men and women did not differ with regard to the SAT. In both males and females VAT and VAT/SAT ratio were significantly higher in patients with schizophrenia than in healthy individuals (Table 2). Within schizophrenia groups the only demographic variable that correlated positively with visceral obesity, namely with VAT/SAT ratio was the length of the disease, however, this type of relationship was observed exclusively among males (Spearman correlation $\mathrm{r}=0.51, \mathrm{p}=0.01, \mathrm{n}=23$ ). There were no significant differences between men and women with respect to the onset of schizophrenia and the duration of the disease.

Multiple regression analysis for the detailed body composition characteristics. Healthy women were used as the reference category.

Table 1 Study groups characteristics

\begin{tabular}{|c|c|c|c|c|c|c|}
\hline & \multicolumn{3}{|c|}{ Male } & \multicolumn{3}{|c|}{ Female } \\
\hline & Schizophrenia $\mathrm{N}=33$ & Controls $\mathrm{N}=23$ & $P$ value & Schizophrenia $\mathrm{N}=19$ & Controls $\mathrm{N}=22$ & $P$ value \\
\hline Age (years) & $46(31,57)$ & $42(27,53)$ & 0.368 & $41(30,47)$ & $39.5(30,47)$ & 0.990 \\
\hline Body weight (kg) & $70(68,75)$ & $74.4(66,77)$ & 0.133 & $59(54,68)$ & $58.5(54.7,64.2)$ & 0.783 \\
\hline Height (cm) & $175(172,178)$ & $179(170,186)$ & 0.236 & $164(161,170)$ & $167.5(163,170)$ & 0.511 \\
\hline $\mathrm{BMl}$ & $23.3(22.3,24)$ & $23.5(22.3,24.2)$ & 0.516 & $21.8(20.8,24.1)$ & $20.9(20.1,22.1)$ & 0.302 \\
\hline WHR & $0.9(0.9,0.9)$ & $0.9(0.9,0.9)$ & 0.434 & $0.89(0.85,0.92)$ & $0.84(0.79,0.86)$ & 0.009 \\
\hline
\end{tabular}


Table 2 Body composition measurements of patients with schizophrenia and controls

\begin{tabular}{|c|c|c|c|c|c|c|}
\hline & \multicolumn{3}{|c|}{ Males } & \multicolumn{3}{|c|}{ Females } \\
\hline & Schizophrenia $\mathrm{N}=33$ & Controls $\mathrm{N}=\mathbf{2 3}$ & $P$ value & Schizophrenia N = 19 & Controls $\mathrm{N}=\mathbf{2 1}$ & $P$ value \\
\hline Fat free mass $(\mathrm{kg})$ & $57.2(54,59.9)$ & $62.5(54.8,66)$ & 0.010 & $43.4(41.8,45.6)$ & $44.7(42.6,46.1)$ & 0.229 \\
\hline Fat free mass (\%) & $81.2(78.8,85)$ & $83.9(78.5,86.5)$ & 0.286 & $72.8(70.1,77.4)$ & $74.5(70.1,77.3)$ & 0.804 \\
\hline Body fat $(\mathrm{kg})$ & $13.3(10,15.7)$ & $11.5(10.3,16.3)$ & 0.653 & $16(12.2,19.3)$ & $15.3(12.5,18.3)$ & 0.824 \\
\hline$\%$ Body fat & $18.8(14.4,21.2)$ & $16.1(13.5,19.7)$ & 0.194 & $27.2(22.6,29.9)$ & $25.5(22.7,29.9)$ & 0.695 \\
\hline RMR (kcal) & $1798(1585,1885)$ & $1820(1704,2120)$ & 0.050 & $1427(1390,1517)$ & $1479(1435,1520)$ & 0.472 \\
\hline $\operatorname{VAT}\left(\mathrm{cm}^{2}\right)$ & $351.9(262,586.8)$ & $73(52,201)$ & 0.000 & $124(56,281)$ & $55.5(39,84)$ & 0.006 \\
\hline SAT $\left(\mathrm{cm}^{2}\right)$ & $88(80,112)$ & $108(78,139)$ & 0.286 & $82(65,92)$ & $80.5(73,101)$ & 0.565 \\
\hline VAT/SAT ratio & $3.5(2.5,5)$ & $0.7(0.5,1.9)$ & 0.000 & $1.4(0.6,3.5)$ & $0.7(0.5,1)$ & 0.005 \\
\hline
\end{tabular}

The results of the regression analyses examining the associations between the diagnosis of schizophrenia and body composition in normal-weight patients with schizophrenia are presented in Table 3. Schizophrenia was significantly associated with lower fat- free mass $(\mathrm{kg})$, higher VAT and VAT/SAT ratio. There was a close relationship between the male gender and higher VAT and VAT/SAT ratio. Subjects' age and BMI were positively related to higher values of fat mass $(\mathrm{kg})$ but inversely with $\%$ fat free mass.

The analysis of the food intake showed that daily food rations of men with schizophrenia compared to those of healthy subjects provided less kcal/day. Also glucose, proteins and fibre consumption was lower in this group. On the other hand, the mean intake of saturated fats in the diets of women with schizophrenia was higher compared to controls (Tables 4 and 5). Daily food rations of men with schizophrenia provided lower amounts of vitamins (B2, C) and minerals (zinc, magnesium, iron, copper, calcium). Additionally, the intake of vitamin D3, C, folic acid, calcium, magnesium in men, and in women with schizophrenia also iron, did not cover daily requirements for these components (RDA) (Tables 6 and 7).

In female group, the presence of high amount of saturated fatty acids in their diet was positively related to fat mass (kg) (women with schizophrenia, $\mathrm{r}=0.73, \mathrm{p}=$ $0.0007, \mathrm{n}=17$ ). In women with schizophrenia and in their controls, the amount of magnesium, niacin, vitamin B6, and in men diagnosed with schizophrenia, lower zinc and vitamin $\mathrm{C}$, was inversely correlated with the VAT or VAT/SAT ratio (Table 8).

\section{Discussion}

This study was the first to compare body composition of normal-weight, non-diabetic, chronic schizophrenia patients with that of healthy controls. The main findings of this study were that both normal-weight men and women with schizophrenia had visceral fat content significantly higher compared to that of the control groups, while there was no difference with respect to the
Table 3 Multiple regression analysis for the detailed body composition characteristic

\begin{tabular}{|c|c|c|c|c|}
\hline & & Beta coefficient & $P$ value & $\mathrm{R}^{2}$ \\
\hline \multicolumn{5}{|l|}{ Fat free mass (kg) } \\
\hline & Gender & 14.101 & $P<0.001$ & \\
\hline & Schizophrenia & -2.990 & 0.001 & 0.757 \\
\hline & Age & -0.134 & $P<0.001$ & \\
\hline & $\mathrm{BMI}$ & 0.925 & $P=0.001$ & \\
\hline \multicolumn{5}{|l|}{ Fat free mass (\%) } \\
\hline & Gender & 11.546 & $P<0.001$ & \\
\hline & Schizophrenia & -0.496 & 0.376 & 0.801 \\
\hline & Age & -0.105 & $P<0.001$ & \\
\hline & $\mathrm{BMI}$ & -2.123 & $P<0.001$ & \\
\hline \multicolumn{5}{|l|}{ Body fat (kg) } \\
\hline & Gender & -6.109 & $P<0.001$ & \\
\hline & Schizophrenia & -0.063 & 0.899 & 0.697 \\
\hline & Age & 0.006 & 0.004 & \\
\hline & BMl & 2.023 & $P<0.001$ & \\
\hline \multicolumn{5}{|l|}{ Body fat (\%) } \\
\hline & Gender & -11.642 & $P<0.001$ & \\
\hline & Schizoprenia & 0.646 & 0.268 & 0.788 \\
\hline & Age & 0.106 & $P<0.001$ & \\
\hline & $\mathrm{BMI}$ & 2.051 & $P<0.001$ & \\
\hline \multicolumn{5}{|l|}{ VAT } \\
\hline & Gender & 169.451 & $<0.001$ & \\
\hline & Schizophrenia & 201.670 & $P<0.001$ & 0.325 \\
\hline & Age & 1.170 & 0.457 & \\
\hline & $\mathrm{BMI}$ & -4.729 & 0.701 & \\
\hline \multicolumn{5}{|l|}{ VAT/SAT } \\
\hline & Gender & 1.585 & 0.001 & \\
\hline & Schizophrenia & 2.098 & $P<0.001$ & 0.280 \\
\hline & Age & 0.019 & 0.265 & \\
\hline & $\mathrm{BMI}$ & -0.171 & 0.207 & \\
\hline
\end{tabular}


Table 4 Energy and nutritional value of daily food rations of the male study participants

\begin{tabular}{|c|c|c|c|c|c|}
\hline & Schizophrenia $(N=27)$ & & Controls $(\mathrm{N}=22)$ & & \\
\hline & Median (IQR) & $\begin{array}{l}\% \text { realization of } \\
\text { the norm and } \\
\text { recommendations }\end{array}$ & Median (IQR) & $\begin{array}{l}\% \text { realization of } \\
\text { the norm and } \\
\text { recommendations }\end{array}$ & $P$ value \\
\hline Energy (kcal) & $1719.9(1464.8,2313.3)$ & 63.7 & $2114.4(1855.5,2722)$ & 78.3 & 0.021 \\
\hline Water (ml) & $1537(1234.4,1820.6)$ & 41.5 & $1700.4(1413.8,2462.4)$ & 45.9 & 0.07 \\
\hline Proteins (total) (g) & $62.6(52.8,86)$ & 77.2 & $102.2(68.9,108.5)$ & 126.1 & 0.004 \\
\hline Proteins (animal) (g) & $44.1(32.9,52.2)$ & 110.2 & $70.2(40.9,85.2)$ & 175.5 & 0.015 \\
\hline Fat (g) & $67.2(48,91.3)$ & 74.6 & $73.4(53.7,103.2)$ & 81.5 & 0.594 \\
\hline Carbohydrates total (g) & $235.2(152.6,274.4)$ & 60.1 & $320.3(219.3,374.7)$ & 81.9 & 0.011 \\
\hline Saturated fatty acids (g) & $32.2(17.8,39.7)$ & 107.3 & $27.9(22.1,39.6)$ & 93.0 & 0.786 \\
\hline Monounsaturated fatty acids (g) & $27.4(19.5,39.6)$ & 76.1 & $27.5(21,150.3)$ & 76.3 & 0.771 \\
\hline Polyunsaturated fatty acids (g) & $6.8(4.1,9.8)$ & 28.3 & $7.9(5.7,12.6)$ & 32.9 & 0.140 \\
\hline Cholesterol (mg) & $240.7(187.3,417)$ & 80.2 & $306.2(233.1,484.6)$ & 102.0 & 0.540 \\
\hline Fibre $(m g)$ & $14.8(49.3 \%)(11.4,18.1)$ & 49.3 & $18.3(14.5,25.7)$ & 61.0 & 0.041 \\
\hline
\end{tabular}

amount of subcutaneous adipose tissue (SAT). Although in both males and females with schizophrenia visceral adiposity was higher compared to controls, mainly the male gender was associated with higher values of VAT, VAT/SAT ratio. The mechanism for increased visceral fat in schizophrenic patients has not been completely elucidated. Patients with schizophrenia are at risk of developing obesity due to poor dietary habits, lower resting energy expenditure, lack of exercise or limited activity due to negative symptoms of schizophrenia. Previous studies have suggested an increased propensity for storing excess fat as visceral adiposity in schizophrenic patients [12,14]. Ryan at al. (2004) have shown that even first episode, drug-naïve patients with schizophrenia had over three times as much visceral fat as BMI-matched controls. In their study, drug-naïve patients with schizophrenia were hypercortisolemic, consumed less fibre though more saturated fat, had higher WHRs, and had just over 3 times as much VAT as the BMI matched group of control subjects [12]. According to the authors, the most likely pathophysiological mechanism underlying this increase in visceral obesity in schizophrenia was hypercortisolemia. High levels of cortisol primarily increase LPL activity, and do so to a greater extent in VAT fat cells, thereby leading to a greater deposition of visceral fat [25]. Ryan et al. (2004) also analysed the impact of risperidone and olanzapine treatment on VAT and concluded that they do not appear to play a part in the generation of excessive levels of visceral fat in their group of never-treated patients with schizophrenia [12].

Our sample, in contrast to the previous study, consisted of patients with normal weight $\left(\mathrm{BMI}<25 \mathrm{~kg} / \mathrm{m}^{2}\right)$

Table 5 Energy and nutritional value of daily food rations of the female participants

\begin{tabular}{|c|c|c|c|c|c|}
\hline & \multicolumn{2}{|l|}{ Schizophrenia $(N=17)$} & \multicolumn{2}{|l|}{ Controls $(\mathrm{N}=20)$} & \multirow[b]{2}{*}{$P$ value } \\
\hline & Median (IQR) & $\begin{array}{l}\text { \% realization of } \\
\text { the norm and } \\
\text { recommendation }\end{array}$ & Median (IQR) & $\begin{array}{l}\% \text { realization of } \\
\text { the norm and } \\
\text { recommendation }\end{array}$ & \\
\hline Energy (kcal) & $1621.3(1460.1,1915.3)$ & 77.2 & $1378.8(1131,1636)$ & 65.6 & 0.057 \\
\hline Water (ml) & $1561.4(1376.4,1711.3)$ & 57.8 & $1804.5(1386.3,2230.8)$ & 66.8 & 0.156 \\
\hline Proteins (total) (g) & $64.2(53.8,69.1)$ & 101.9 & $59.5(54.3,93.1)$ & 94.4 & 0.532 \\
\hline Proteins (animal) (g) & $37.8(29.7,48.5)$ & 118.1 & $45.9(35.9,67.8)$ & 143.4 & 0.065 \\
\hline Fat (g) & $44.3(40.1,58.5)$ & 63.3 & $37.8(25.9,57.5)$ & 54 & 0.097 \\
\hline Carbohydrates total (g) & $253.3(183,306.5)$ & 83.3 & $182.8(144.9,221.2)$ & 60.1 & 0.070 \\
\hline Saturated fatty acids (g) & $20(16.5,27.9)$ & 86.9 & $14.4(10.4,20.1)$ & 62.6 & 0.034 \\
\hline Monounsaturated fatty acids (g) & $17.4(16.3,29.2)$ & 62.1 & $14.4(9.7,23)$ & 51.4 & 0.110 \\
\hline Polyunsaturated fatty acids (g) & $5.2(4.2,5.6)$ & 27.4 & $4.4(3.7,5.5)$ & 23.1 & 0.353 \\
\hline Cholesterol (mg) & $190.7(157.6,252.4)$ & 63.6 & $194.8(127.8,266.5)$ & 64.9 & 0.915 \\
\hline Fibre (mg) & $16.2(13.3,209)$ & 54 & $14.9(12.1,17.4)$ & 49.6 & 0.511 \\
\hline
\end{tabular}


Table 6 Supply of vitamins and minerals in daily food rations (male participants)

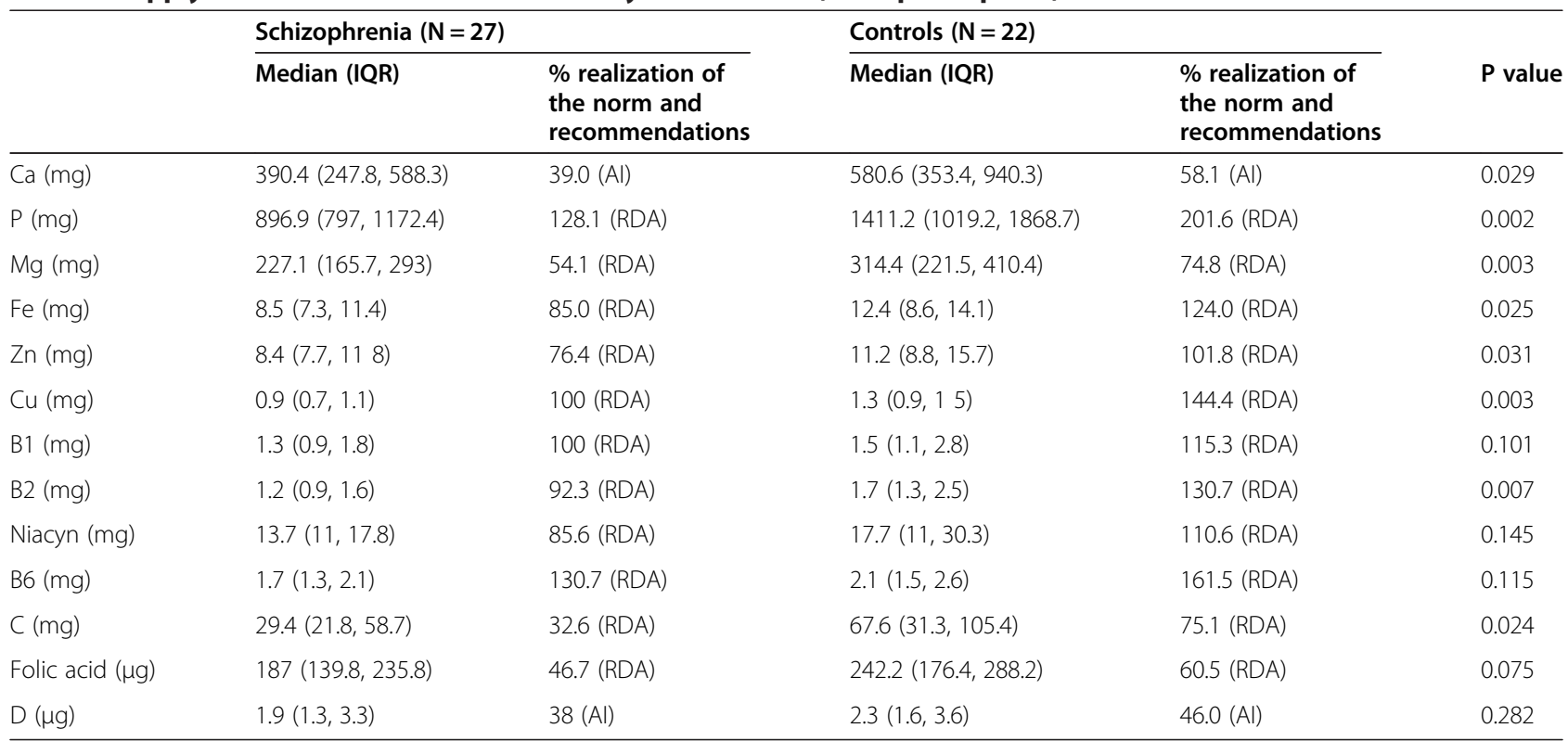

RDA-Recommended Dietary Allowances; Al-Adequate Intake.

for many years exposed to neuroleptic treatment. Males were more prone to higher VAT levels although the mean intake of absorbable carbohydrates and saturated fats in the diets of women with schizophrenia was higher, as compared to controls. Men had over 5 times, while women over 2 times as much VAT as the BMImatched groups did. Both BMI and age of the patients did not affect the contents of the VAT. Higher VAT and lower fat free mass $(\mathrm{kg})$ was directly related to schizophrenia, while body fat mass positively correlated with the subjects' age and BMI. Our results turned to be only partly consistent with other studies investigating body mass composition in schizophrenia patients chronically exposed to neuroleptic treatment. In a study by Sugawara et al. (2012), schizophrenia was significantly linked with more body fat, higher \% body fat and lower fat- free mass [26]. Contrary to men, in women schizophrenia had a significant association with lower \% body fat, higher fat- free mass, higher muscle mass. In turn, Nilsson et al. (2006) found that patients with schizophrenia had higher \% body

Table 7 Supply of vitamins and minerals in daily food rations (female participants)

\begin{tabular}{|c|c|c|c|c|c|}
\hline & \multicolumn{2}{|l|}{ Schizophrenia $(\mathrm{N}=17)$} & \multicolumn{2}{|l|}{ Controls $(\mathrm{N}=20)$} & \multirow[b]{2}{*}{$P$ value } \\
\hline & Median (IQR) & $\begin{array}{l}\% \text { realization of } \\
\text { the norm and } \\
\text { recommendations }\end{array}$ & Median (IQR) & $\begin{array}{l}\% \text { realization of } \\
\text { the norm and } \\
\text { recommendations }\end{array}$ & \\
\hline$\overline{\mathrm{Ca}(\mathrm{mg})}$ & $474.1(208.6,616.3)$ & 47.4 (Al) & $434.6(280.2,612.1)$ & 43.5 (Al) & 0.988 \\
\hline$P(m g)$ & $1068.6(806.5,1262.1)$ & 152.6 (RDA) & $1088(837.5,1248.7)$ & 108.8 (RDA) & 0.796 \\
\hline $\mathrm{Mg}(\mathrm{mg})$ & $261.7(175.2,360.3)$ & 81.8 (RDA) & $222.8(177.5,306.1)$ & 69.6 (RDA) & 0.939 \\
\hline $\mathrm{Fe}(\mathrm{mg})$ & $8.4(7.4,10)$ & 46.6 (RDA) & $7.4(6.1,10.6)$ & 41.1 (RDA) & 0.512 \\
\hline Zn (mg) & $8.6(7.3,9.9)$ & 107.5 (RDA) & $8.2(5.5,10.4)$ & 102.5 (RDA) & 0.552 \\
\hline $\mathrm{Cu}(\mathrm{mg})$ & $0.8(0.6,1.1)$ & 88.8 (RDA) & $0.9(0.7,1.1)$ & 100 (RDA) & 0.784 \\
\hline B1 (mg) & $1.0(0.8,1.2)$ & 90.9 (RDA) & $1.1(0.8,1.3)$ & 90.9 (RDA) & 0.879 \\
\hline B2 (mg) & $1.2(0.8,1.5)$ & 109 (RDA) & $1.3(1.2,1.6)$ & 108.3 (RDA) & 0.377 \\
\hline Niacyn (mg) & $10.3(6.4,16.7)$ & 73.6 (RDA) & $12.7(8.3,24.3)$ & 90.7 (RDA) & 0.124 \\
\hline B6 (mg) & $1.3(1,1.5)$ & 100 (RDA) & $1.5(1.4,1.7)$ & 115.4 (RDA) & 0.097 \\
\hline$C(\mathrm{mg})$ & $31.9(17.5,40.7)$ & $42.5(\mathrm{RDA})$ & $60.7(32.6,108.9)$ & 80.9 (RDA) & 0.020 \\
\hline Folic acid $(\mu \mathrm{g})$ & $164.7(139.8,204.9)$ & $41.2(\mathrm{RDA})$ & $186.6(161,231.8)$ & 46.6 (RDA) & 0.110 \\
\hline$D(\mu g)$ & $1.3(0.9,2.1)$ & 26 (Al) & $1.6(0.9,2.1)$ & $32(\mathrm{Al})$ & 0.927 \\
\hline
\end{tabular}

RDA-Recommended Dietary Allowances; Al-Adequate Intake. 
Table 8 Spearman rank correlations between nutrients and VAT ${ }^{1}$ or VAT/SAT ratio ${ }^{2}$

\begin{tabular}{|c|c|c|c|c|c|c|c|c|c|}
\hline & \multicolumn{4}{|c|}{ Female } & & \multicolumn{4}{|l|}{ Males } \\
\hline & \multicolumn{2}{|c|}{ Schizophrenia } & \multicolumn{2}{|c|}{ Controls } & & \multicolumn{2}{|c|}{ Schizophrenia } & \multicolumn{2}{|c|}{ Controls } \\
\hline & $\mathrm{R}$ & $P$ & $\mathbf{R}$ & $P$ & & $\mathbf{R}$ & $P$ & $\mathrm{R}$ & $P$ \\
\hline Niacin & -0.50 & $0.04^{2}$ & -0.52 & $0.02^{2}$ & Vit. C & -0.47 & $0.01^{2}$ & -0.51 & $0.01^{2}$ \\
\hline Vit. B6 & -0.63 & $0.006^{1}$ & -0.5 & $0.02^{2}$ & $\mathrm{Zn}$ & -0.45 & $0.02^{2}$ & - & - \\
\hline $\mathrm{Mg}$ & -0.60 & $0.01^{1}$ & -0.47 & $0.04^{1}$ & - & - & - & - & - \\
\hline
\end{tabular}

fat and lower fat- free mass than healthy controls [27]. Saarni et al. (2009) reported that schizophrenia was significantly associated with a higher \% body fat and lower fat- free mass after adjusting for age, gender, and BMI [13]. Nevertheless, all of these studies showed smaller content of the fat free mass in patients with schizophrenia. The differences between our results and data from other studies may be due to the fact that the previous studies included patients who were overweight, samples were not always BMI- matched and the body fat content was not differentiated in terms of its location: into visceral and subcutaneous fat depot. Most previous studies also used different methods than BIA, and analyzed a mixed subject pool of both genders or only male subjects.

In our chronically treated patients, the only demographic variable that correlated positively with visceral depot besides schizophrenia was the length of the disease. However, this type of relationship was observed exclusively among males. This may be partially explained by the use of antipsychotic medication and unhealthy lifestyle habits. Antipsychotic medications, especially atypical, have been associated with significant weight gain and visceral obesity [28]. In Zhang et al. (2004) study an antipsychotic drug treatment rapidly induces abdominal fat deposition and hyperlipidaemia. Therefore, it may be possible for older subjects with a longer duration of the disease to have higher VAT, since normally they have been on antipsychotic medication for a longer period of time.

Another factor which was related with the amount of VAT in our study was the components of the patients' diet. In women with schizophrenia, the presence of high amount of saturated fatty acids in their diet was positively related to fat mass. The analysis of the food intake showed that daily food rations of men diagnosed with schizophrenia provided less calories, proteins, glucose and fibre compared to controls, whereas women, while providing a similar amount of calories, tend to eat more saturated fatty acids. The results of our study point to the fact that patients with schizophrenia with normal weight do not have a tendency to consume excessive amounts of calories, quite the contrary. Thus, the accumulation of visceral fat in this group may be due to improper composition of the food rather than due to excessive daily calorie intake. Daily food rations of men diagnosed with schizophrenia provided also smaller amounts of vitamins (B2, C) and minerals (zinc, magnesium, iron, copper, calcium). In women with schizophrenia and in their controls, the amount of magnesium, niacin and vitamin B6 in their diet was inversely correlated with the VAT, while in men lower zinc and vitamin $C$ intake was related to higher visceral adiposity. Numerous studies have provided evidence that the abovementioned components of the diet are associated with energy metabolism. Magnesium has been linked with a number of chronic diseases, including diabetes, hypertension and lipid abnormalities [29]. Magnesium deficiency [30] was described a common factor associated with insulin resistance [31], which impairs energy metabolism efficiency and reduces the capacity for physical work, exerts negative effects on blood glucose homeostasis, and is independently associated with depressive symptoms [32-35]. In addition, magnesium intake in two studies was inversely associated with the metabolic syndrome and risk of type 2 DM [36]. In turn, niacin has been reported to decrease VLDL, LDL and small dense LDL particles and increase HDL levels resulting in an overall beneficial lipoprotein profile. Niacin in Kamanna and Kashyap (2000) study reduced plasma free fatty acid levels by inhibiting adipose tissue lipolysis, thereby decreasing available substrate for hepatic VLDL synthesis [37]. Niacin, alone or in combination with statins, has demonstrated effectiveness in reducing the progression of atherosclerosis in hypertriglyceridemic individuals with coronary disease in old or small studies [37-39]. Vitamin $B_{6}$, although not directly related with energy metabolism, is essential for the brain regional synthesis of 5-HT (serotonin). In turn, serotonin has been implicated in various CNS functions that regulate sleep onset, blood pressure, mood but also food intake satiety $[40,41]$. In turn, zinc ions in Chen et al. study (1988) influenced adipose tissue metabolism by regulating leptin secretion and by promoting free fatty acid release and glucose uptake [42]. Apart from participating in the control of leptin secretion, zinc also seems to be intimately involved in glucose- and fat-metabolism in adipocytes, where zinc per se has a role as an insulinomimetic [43]. There is clear evidence that visceral obesity is associated with increased oxidative stress and inflammation [44]. Another recent data also suggest that dietary antioxidants, 
including vitamin $C$ intake may be a predictor of the risk to develop metabolic syndrome features such as adiposity or impairments in systolic blood pressure, serum glucose and free fatty acids, and some inflammatory biomarkers in healthy subjects [45].

\section{Conclusions}

It is difficult to draw conclusions from this study as its limitations include a relatively small sample size and the fact that daily food rations were evaluated by a method covering 3 days preceding the examination. Despite these shortcomings, our study has shown that normal weight patients with chronic schizophrenia have higher levels of visceral fat than controls but a similar volume of SAT. Although in both males and females with schizophrenia the visceral adiposity was higher compared to controls, mainly the male gender was associated with higher values of VAT and the VAT/SAT ratio. Schizophrenia patients have poor nutritional patterns. Although no clear conclusion can be drawn regarding cause-and-effect relationships between the dietary content of food served to our patients and visceral obesity we suggest that schizophrenic diet should be further investigated as a possible factor related to this type of obesity.

\section{Competing interests}

The authors of this manuscript have no conflicts of interest to disclose as described by the Journal.

\section{Authors' contributions}

BK conceived the study, designed the study, interpreted the data and wrote the initial draft of the manuscript. AS, ES and LO contributed to study design and assisted in drafting the manuscript. UC conducted the statistical analysis. ES, AW, UC had full access to all of the data in the study and take responsibility for the integrity of the data and the accuracy of the data analysis. UK, ES, AW, AG, AM, LO, LR completed recruitment of participants. All authors have approved the manuscript.

\section{Author details}

${ }^{1}$ Department of Psychiatry, Medical University of Bialystok, Plac Brodowicza 1, Choroszcz 16-070, Poland. '2Department of Dietetics and Clinical Nutrition, Medical University of Bialystok, Mieszka I-go 4B, Białystok 15-054, Poland. ${ }^{3}$ Department of Statistics and Medical Informatics, Medical University of Bialystok, Szpitalna 37, Białystok 15-295, Poland. ${ }^{4}$ Department of Psychiatry, Medical University of Warsaw, Faculty of Health Sciences, ul. Partyzantow 2/4, Pruszkow 05-802, Poland.

Received: 29 December 2013 Accepted: 5 February 2014 Published: 8 February 2014

\section{References}

1. Ruderman N, Chisholm D, Pi-Sunyer X, Schneider S: The metabolically obese, normal-weight individual revisited. Diabetes 1998, 47:699-713.

2. Björntorp P: Abdominal obesity and the development of noninsulindependent diabetes mellitus. Diabetes Metab Rev 1988, 4:615-622.

3. Carey VJ, Walters EE, Colditz GA, et al: Body fat distribution and risk of non-insulin-dependent diabetes mellitus in women. The Nurses' health study. Am J Epidemiol 1997, 145:614-619.

4. Wang J, Liu EY, Freudenreich O, Goff D, Henderson DC, Fan X: Phenotypic characteristics in metabolically obese but normal weight non-diabetic patients with schizophrenia. Schizophr Res 2010, 124(1-3):49-53.
5. Dickerson FB, Brown CH, Kreyenbuhl JA, Fang L, Goldberg RW, Wohlheiter K, Dixon LB: Obesity among individuals with serious mental illness. Acta Psychiatr Scand 2006, 113:306-313.

6. Susce MT, Villanueva N, Diaz FJ, de Leon J: Obesity and associated complications in patients with severe mental illnesses: a cross-sectional survey. J Clin Psychiatry 2005, 66:167-173.

7. Amani R: Is dietary pattern of schizophrenia patients different from healthy subjects? BMC Psychiatry 2007, 7:1-5.

8. Peet M: Nutrition and schizophrenia: beyond omega-3 fatty acids. Prostaglandins Leukot Essent Fat Acids 2004, 70:417-422.

9. Pate RR, O'Neill JR, Lobelo F: The evolving defınition of "sedentary". Exerc Sport Sci Rev 2008, 36:173-178.

10. Sharpe JK, Stedman TJ, Byrne NM, Wishart C, Hills AP: Energy expenditure and physical activity in clozapine use: implications for weight management. Aust N Z J Psychiatry 2006, 40(12):810-814.

11. Vancampfort D, Probst M, Knapen J, Carraro A, De Hert M: Associations between sedentary behaviour and metabolic parameters in patients with schizophrenia. Psych Res 2012, 200(2/3):73-78.

12. Ryan M, Flanagan S, Kinsella U, Keeling F, Thakore J: The effects of atypical antipsychotics on visceral fat distribution in first episode, drug-naive patients with schizophrenia. Life Sci 2004, 74(16):1999-2008.

13. Saarni SE, Saarni SI, Fogelholm M, Heliövaara M, Perälä J, Suvisaari J, Lönnqvist J: Body composition in psychotic disorders: a general population survey. Psychol Med 2009, 39:801-810.

14. Thakore JH, Mann JN, Vlahos I, Martin A, Reznek R: Increased visceral fat distribution in drug-naive and drug-free patients with schizophrenia. Int J Obes Relat Metab Disord 2002, 26:137-141.

15. Sharpe J, Byrne N, Stedman T, Hills A: Bioelectric impedance is a better indicator of obesity in men with schizophrenia than body mass index. Psychiatry Res 2008, 159(1/2):121-126.

16. Boneva-Asiova Z, Boyanov MA: Body composition analysis by leg-to-leg bioelectrical impedance and dual-energy X-ray absorptiometry in nonobese and obese individuals. Diabetes Obes Metab 2008, 10:1012-1018.

17. Ellis KJ: Human body composition: in vivo methods. Psychol Rev 2000, 80(2):649-680.

18. Kitano T, Kitano N, Inomoto T, Futatsuka M: Evaluation of body composition using dual-energy X-ray absorptiometry, skinfold thickness and bioelectrical impedance analysis in Japanese female college students. J Nutr Sci Vitaminol 2001, 47:122-125.

19. Meng-Yueh C, Hsu-Ko K, Ying-Tai W: Sarcopenia, cardiopulmonary fitness, and physical disability in community-dwelling elderly people. Phys Ther 2010, 90(9):1277-1287.

20. Lukaski HC, Johnson PE, Bolonchuk WW, Lykken Gl: Assessment of fat-free mass using bioelectrical impedance measurements of the human body. Am J Clin Nutr 1985, 41:810-817.

21. Segal KR, Van Loan M, Fitzgerald PI, et al: Lean body mass estimation by bioelectrical impedance analysis: a four-site cross-validation study. Am J Clin Nutr 1988, 47:7-14

22. Jackson AS, Pollock ML, Graves JE, Mahar MT: Reliability and validity of bioelectrical impedance in determining body composition. $J$ App/ Physiol 1988, 64:529-534.

23. Rychlik E: Album fotografii produktów i potraw. Warszawa: Instytut Żywności i Żywienia; 2000.

24. Jarosz M: Normy żywienia dla populacji polskiej - nowelizacja. Warszawa: Instytut Żywności i Żywienia; 2012.

25. Ottoson M, Vikman-Adolfson K, Enerback S, Olivecrona G, Bjorntorp P: The effects of cortisol on the regulation of lipoprotein lipase activity in human adipose tissue. J Clin Endocrinol Metabol 1994, 79:820-825.

26. Sugawara N, Yasui-Furukori N, Tsuchimine S, Fujii A, Sato Y, Saito M, Kaneko S: Body composition in patients with schizophrenia: Comparison with healthy controls. Annals Of General Psychiatry 2012, 11(1):11-15.

27. Nilsson BM, Forslund AH, Olsson RM, Hambraeus L, Wiesel FA: Differences in resting energy expenditure and body composition between patients with schizophrenia and healthy controls. Acta Psychiatr Scand 2006, 114:27-35.

28. Zhang ZJ, Yao ZJ, Liu W, et al: Effects of antipsychotics on fat deposition and changes in leptin and insulin levels. Magnetic resonance imaging study of previously untreated people with schizophrenia. Br J Psychiatry 2004, 184:58-62

29. Swaminathan R: Magnesium metabolism and its disorders. Clin Biochem Rev 2003, 24(2):47-66. 
30. Wild S, Roglic G, Green A, Sicree R, King H: Global prevalence of diabetes: estimates for the year 2000 and projections for 2030. Diabetes Care 2004, 27(5):1047-1053.

31. Nadler JL, Buchanan T, Natarajan R, Antonipillai I, Bergman R, Rude R: Magnesium deficiency produces insulin resistance and increased thromboxane synthesis. Hypertension 1993, 21:1024-1029.

32. Huang ES, Liu JY, Moffet HH, John PM, Karter AJ: Glycemic control, complications, and death in older diabetic patients the diabetes and aging study. Diabetes Care 2011, 34(6):1329-1336.

33. de Boer IH, Katz R, Cao JJ, Fried LF, Kestenbaum B, Mukamal K, et al: Cystatin $C$, albuminuria, and mortality among older adults with diabetes. Diabetes Care 2009, 32(10):1833-1838.

34. Nielsen FH, Milne DB, Klevay LM, Gallagher S, Johnson L: Dietary magnesium deficiency induces heart rhythm changes, impairs glucose tolerance, and decreases serum cholesterol in postmenopausal women. J Am Coll Nut 2007, 26(2):121-132.

35. Barragan-Rodriguez L, Rodriguez-Moran M, Guerrero-Romero F: Depressive symptoms and hypomagnesemia in older diabetic subjects. Arch Med Res 2007, 38(7):752-756.

36. Dong JY, Xun P, He K, Qin LQ: Magnesium intake and risk of type 2 diabetes: meta-analysis of prospective cohort studies. Diabetes Care 2011, 34(9):2116-2122.

37. Kamanna VS, Kashyap ML: Mechanism of action of niacin on lipoprotein metabolism. Curr Atheroscler Rep 2000, 2:36-46.

38. Canner PL, Berge KG, Wenger J, Stamler L, Friedman L, Prineas RJ, Friedewald W: Fifteen year mortality in Coronary Drug Project patients: long-term benefit with niacin. Am Coll Cardiol 1986, 8:1245-1255.

39. Brown BG, Zhao XQ, Chait A, Fisher LD, Cheung MC, Morse JS, Dowdy AA, Marino E, Bolson E, Alaupovic PJ, Frohlich J, Albers JJ: Simvastatin and niacin, antioxidant vitamins, or the combination for the prevention of coronary disease. N Engl J Med 2001, 345:1583-1592.

40. Young SN, Gauthier S: Effect of tryptophan administration on tryptophan, 5-hydroxyindoleacetic acid, and indoleacetic acid in human lumbar and cisternal cerebrospinal fluid. J Neurol Neurosurg Psychiatry 1981, 44:323-327.

41. Wurtman RJ, Wurtman JJ: Brain serotonin, carbohydrate-craving, obesity and depression. Obes Res 1995, 4:477-480.

42. Chen MD, Lin PY, Lin WH, Cheng V: Zinc in hair and serum of obese individuals in Taiwan. Am J Clin Nutr 1988, 48:1307-1309.

43. Liuzzi JP, Lichten LA, Rivera S, Blanchard SK, Aydemir TB, Knutson MD, Ganz T, Cousins RJ: Interleukin- 6 regulates the zinc transporter Zip14 in liver and contributes to the hypozincemia of the acute-phase response. Proc Natl Acad Sci USA 2005, 102:6843-6848.

44. Gariballa, et al: Oxidative damage and inflammation in obese diabetic Emirati subjects supplemented with antioxidants and B-vitamins: a randomized placebo-controlled trail. Nutr Metab 2013, 10:21.

45. Puchau B, Zulet A, Gonzalez A, Hermsdorff H, Martinez J: Dietary total antioxidant capacity is negatively associated with some metabolic syndrome features in healthy young men. Nutrition 2010, 26:534-541.

doi:10.1186/1471-244X-14-35

Cite this article as: Konarzewska et al.: Visceral obesity in normal-weight patients suffering from chronic schizophrenia. BMC Psychiatry 2014 14:35.

\section{Submit your next manuscript to BioMed Central and take full advantage of:}

- Convenient online submission

- Thorough peer review

- No space constraints or color figure charges

- Immediate publication on acceptance

- Inclusion in PubMed, CAS, Scopus and Google Scholar

- Research which is freely available for redistribution

Submit your manuscript at www.biomedcentral.com/submit 